\title{
PENGEMBANGAN MEDIA BERBASIS APLIKASI PADA HANDPHONE UNTUK MENDUKUNG PEMBELAJARAN MATA KULIAH MEDIA REAGEN DENGAN MODEL PROBLEM BASED LEARNING DIPADU PENDEKATAN BLESS
}

\author{
Wimpy $^{1}$, Sri Mulyani ${ }^{2}$, Ashadi $^{3}$ \\ ${ }^{1}$ Program Studi Magister Pendidikan Sains FKIP Universitas Sebelas Maret \\ Surakarta, 57126, Indonesia \\ wimpyzabarjad86@gmail.com \\ ${ }^{2}$ Program Studi Magister Pendidikan Sains FKIP Universitas Sebelas Maret \\ Surakarta, 57126, Indonesia \\ srimulyaniuns@gmail.com \\ ${ }^{3}$ Program Studi Magister Pendidikan Sains FKIP Universitas Sebelas Maret \\ Surakarta, 57126, Indonesia \\ ashadiuns2014@gmail.com
}

\begin{abstract}
Abstrak
Tujuan penelitian ini untuk mengetahui hasil dari tiap tahap pengembangan, kualitas dari aspek desain/ materi dan aspek media serta keefektifan media berbasis aplikasi pada handphone yang dikembangkan untuk mendukung pembelajaran mata kuliah media reagen dengan model Problem Based Learning dipadu pendekatan BLESS (Blended Learning Systems Structures) mahasiswa DIII Akademi Analis Kesehatan Nasional Surakarta. Penelitian ini merupakan penelitian dan pengembangan (R\&D) yang mengacu pada model Borg \& Gall dilaksanakan dari bulan Januari 2014 hingga Maret 2015 di Akademi Analis Kesehatan Nasional Surakarta. Data diambil dengan teknik angket, teknik observasi, dan teknik tes. Berdasarkan hasil analisis data, dapat disimpulkan: 1) hasil tiap tahap penelitian dan pengembangan pada: tahap studi pendahuluan disimpulkan bahwa dibutuhkan media berupa aplikasi pada handphone untuk mendukung pembelajaran mata kuliah Media Reagen dengan model PBL dipadu pendekatan BLESS (Blended Learning Systems Structure); tahap pengembangan produk awal dihasilkan draft aplikasi pada handphone yaitu LEMMPER (Learning Media Mobile Program Enriched \& Refined); tahap uji coba awal dihasilkan revisi 1; tahap uji coba lapangan dihasilkan revisi 2, data keterlaksanaan tahapan problem based learning, dan hasil belajar mahasiswa; tahap uji coba operasional dihasilkan produk akhir, 2) kualitas produk pengembangan media berdasarkan penilaian ahli materi dan ahli media diperoleh CV > 0,7 yang menunjukkan bahwa media dapat dilanjutkan ke tahap uji coba; rata-rata angket respon dosen dan mahasiswa pada semua uji diperoleh penilaian dengan kategori "sangat layak". 3) media dikatakan efektif dillihat dari persentase ketuntasan hasil belajar mahasiswa pada pembelajaran mata kuliah media reagen dengan model PBL dipadu pendekatan BLESS mahasiswa reguler $2 \mathrm{C}$ yang didukung dengan media LEMMPER. Hasil presentase ketuntasan klasikal yaitu $100 \%$, sehingga media dikatakan efektif.
\end{abstract}

Kata kunci: BLESS, keefektifan media, kualitas media, LEMMPER.

\section{Pendahuluan}

Perguruan tinggi adalah jenjang pen- didikan tinggi yang merupakan kelanjutan pendidikan menengah seperti tertuang dalam UU No. 20 , pasal 19, tahun 2003. Tujuan pendidikan tinggi seperti yang diatur dalam pasal 2 Peratuan Pemerintah Nomor 60 Tahun 1999 adalah menyiapkan peserta didik menjadi anggota masyarakat yang memiliki kemampuan akademik atau profesional yang dapat menerapkan, mengembangkan ilmu pengetahuan dan teknologi atau kesenian dan mengembang- kan serta menyebarluaskan ilmu pengeta- huan, teknologi, mengupayakan penggu- nannya untuk meningkatkan taraf kehi- dupan masyarakat dan memperkaya kebudayaan nasional. 
Akademi Analis Kesehatan Nasional Surakarta yang mencetak tenaga DIII Analis Kesehatan mempunyai visi yaitu menjadi institusi pendidikan analis kesehatan yang bermutu dan berdaya saing dan mengemban salah satu misi yaitu memenuhi standart mutu pendidikan tertinggi dan berorientasi pada kepuasan pelanggan. Mahasiswa ada- lah salah satu pelanggan yang berhak mendapatkan kualitas pendidikan yang bermutu dan sesuai dengan kompetensi bidangnya. Salah satu standar kompetensi mahasiswa yang belum tecapai yaitu pada standart kompetensi memahami dan menje- laskan serta membuat dan menguji kualitas reagen yang terkait dengan kompetensi dasar mahasiswa dalam menjelaskan dan melaku- kan pembuatan reagen, semua kompetensi dasar tersebut terdapat pada mata kuliah media reagen, ketidaktercapaian standar kompetensi tersebut tercermin pada nilai mata kuliah media reagen tahun ajaran 2011 - 2014, semuanya kurang dari nilai 70,00 seperti disajikan pada Tabel 1 .

Tabel 1. Data Nilai Mata Kuliah Media Reagen Tahun Ajaran $2011-2014$

(BAAK AAK Nasional)

\begin{tabular}{cc} 
& (BAAK AAK Nasional) \\
\hline TahunAjaran & $\begin{array}{l}\text { Nilai rata }- \text { rata mata } \\
\text { kuliah media reagen }\end{array}$ \\
\hline $2011-2012$ (semester genap) & 65,66 \\
$2012-2013$ (semester genap) & 63,91 \\
$2013-2014$ (semester genap) & 68,54 \\
\hline
\end{tabular}

Hal ini juga didukung oleh hasil analisa EMI (Evaluasi Mutu Internal), hasil analisa menunjukkan GAP yang cukup besar, yaitu pada standar 1 , standar isi sebesar $18,57 \%$ dan standar 2, standar proses sebesar 15,08\% seperti disajikan pada Gambar 1.

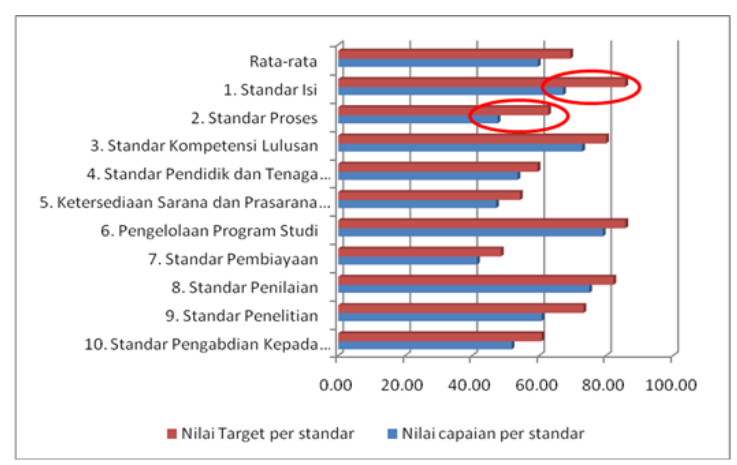

Gambar 1. Grafik Data Perbandingan Target per Standart dan Capaian per Standar
Penyebab pada standar isi yang menghasilkan GAP 18,57 \% salah satunya adalah kurangnya substansi mata kuliah yang berkaitan dengan kompetensi pro- fesional sesuai dengan standar isi mata pelajaran, sedangkan penyebab salah satu GAP pada standar proses sebesar $15,08 \%$ adalah kurang relevannya media yang digunakan untuk proses pembelajaran.

Berdasarkan hasil wawancara yang dilakukan dengan beberapa dosen kimia dan mahasiswa di AAK Nasional Surakarta serta hasil analisis kebutuhan menunjukkan bah- wa media baru dibutuhkan untuk men- dukung pembelajaran media reagen. Pe- ngembangan media pembelajaran berupa aplikasi pada handphone telah menjadi trend dan bahkan telah menjadi nilai jual tersendiri bagi institusi - instusi penyeleng- gara pendidikan.

Problem Based Learning adalah pembelajaran yang digunakan untuk merangsang berpikir tingkat tinggi mahasiswa dalam situasi yang beorientasi pada masalah dunia nyata (Dahar, 2006). Model pembelajaran ini cocok digunakan pada mata kuliah media reagen khususnya materi pembuatan reagen karena dengan model PBL dilandasi oleh teori konstruktivistik, mahasiswa belajar tidak sekedar menghafal, tetapi mahasiswa harus menkonstruksi pengetahuannya secara mandiri. Hal ini juga sesuai dengan penelitian yang dilakukan oleh Akinoglu \& Tandogan (2007: 71-81) dengan hasil bahwa kelompok mahasiswa yang mendapatkan model PBL mendapatkan hasil prestasi lebih baik dibandingkan dengan kelompok yang mendapat pembe- lajaran tradisional. PBL memiliki sintaks sebagai berikut: mengorientasikan maha- siswa kepada masalah, mengorganisasikan mahasiswa untuk belajar, membantu penyelidikan mandiri/ kelompok, mengem- bangkan dan menyajikan hasil karya, menganalisis dan mengevaluasi pemecahan masalah.

Pendekatan pembelajaran BLESS (Blended Learning Systems Structure) adalah pendekatan pembelajaran yang yang dipadukan dengan penggunaan media digital (Staker et al., 2012). Media yang digunakan oleh peneliti berupa aplikasi pada hand-phone. 
Saat ini pendekatan BLESS belum banyak digunakan didalam proses pembe- lajaran. Pembelajaran yang saat ini dilak- sanakan didominasi dengan tatap muka, media pendukung yang digunakan masih berupa media presentasi dengan menggu- nakan Microsoft PowerPoint.

Sehubungan dengan hal tersebut diatas, maka mutlak diperlukan suatu pengembangan media yang sesuai dengan kebutuhan untuk mendukung pembelajaran mata kuliah media reagen dengan model PBL dengan pendekatan BLESS. Salah satu media pembelajaran yang dikembangkan oleh peneliti adalah media berupa aplikasi pada handphone. Media yang akan dikem- bangkan adalah media dengan spesifikasi yaitu berupa aplikasi pada handphone yang bernama LEMMPER (Learning Media Mobile Program Enriched \& Refined) yang dapat dijalankan secara offline maupun online, sehingga tidak tergantung pada konektivitas internet. Aplikasi ini dapat dijalankan di semua jenis handphone berwarna dengan berbagai macam resolusi layar dengan kapasitas memori mencapai 1 Gigabyte. Media LEMMPER ini akan menampilkan standar kompetensi dan kompetensi dasar serta materi perkuliahan yang dilengkapi dengan audio dan video pembelajaran dengan alat evaluasi berupa test pilihan ganda dilengkapi hasil evaluasi yang berisi informasi presentase jawaban yang benar, jumlah halaman yang dibaca, dan lama waktu yang dibutuhkan untuk mengerjakan soal-soal. Media LEMMPER ini digunakan pada pertengahan pertemuan untuk membantu mahasiswa di dalam mencari pemecahan permasalahan. Media ini akan optimal jika diinstall pada handphone dengan ukuran layar 4,5 inchi.

Hasil penelitian yang dilakukan Gustavo \& Nussbaum (2004) yaitu mahasiswa yang menggunakan media mobile computer device memiliki hasil prestasi lebih baik dari pada mahasiswa yang tidak menggunakan. Hasil penelitian Delialioglu (2012, 310-322) menunjukkan hasil prestasi belajar mahasiswa yang menggunakan pembelajaran model problem based dengan pendekatan blended learning lebih baik dibandingkan dengan pembelajaran model lecture - based. Hasil penelitian Poon (2013, 271-289) menghasilkan kesimpulan bahwa blended learning yang diterapkan di negara negara Eropa Timur dan Eropa Tengah sangat efektif untuk membantu komunikasi di dalam proses pembelajaran antara mahasiswa dan perguruan tinggi.

\section{Metode Penelitian}

Penelitian yang dilakukan termasuk dalam penelitian pengembangan, yang mengacu pada pengembangan Research and Development (R\&D) model Borg \& Gall (1983) yang direduksi yakni dilakukan pada sampel yang tidak terlalu besar dan pe- ngembangan yang dilakukan hanya sampai tahapan kesembilan. Produk yang dikem- bangkan berupa media aplikasi pada handphone untuk mendukung mata kuliah media reagen dengan model PBL dipadu pendekatan BLESS.

Tahapan penelitian dan pengembangan pada penelitian ini meliputi : 1) Penelitian dan pengumpulan data (research and information collecting), 2) Perencanaan (planning), 3) Pengembangan draft awal (develop preliminary from product), 4) $\mathrm{Uji}$ coba awal (preliminary field testing), 5) Revisi 1 (main product revision), 6) Uji coba utama (main field testing), 7) Revisi 2 (operating product revision), 8) Uji coba operasional (operational field testing), 9) Penyempurnaan produk akhir (final product revision). Tahap kesepuluh yakni deseminasi dan implementasi tidak dilakukan karena disesuaikan dengan kebutuhan penelitian dan keterbatasan waktu.

Sumber data pada tahap pengem- bangan dan validasi proyek awal dilakukan di Universitas Sebelas Maret Surakarta. Va- lidasi dilakukan oleh dua dosen kimia sebagai ahli materi dan dua dosen ahli media, serta dosen kimia Akademi Analis Kesehatan Nasional Surakarta sebagai praktisi pembelajaran. Tahap uji coba awal di lakukan di AAK Nasional Surakarta dengan jumlah total responden 2 dosen dan 6 mahasiswa reguler 2A. Tahap uji coba utama dilakukan di AAK Nasional Surakarta dengan jumlah total responden sebanyak 2 dosen dan 30 mahasiswa (15 mahasiswa reguler 2B1 dan 15 mahasiswa reguler 2B2). Tahap uji coba 
operasional dilakukan di AAK Nasional Surakarta dengan jumlah total responden sebanyak 2 dosen dan 81 mahasiswa (40 mahasiswa reguler $2 \mathrm{~A}$ dan 41 mahasiswa reguler $2 \mathrm{C}$ ).

Instrumen yang digunakan dalam penelitian pengembangan ini yaitu angket, soal tes, lembar validasi, dan lembar observasi. Pengolahan data dalam penelitian ini dilakukan dengan menggunakan analisis deskriptif, meliputi analisis kelayakan dan analisis data hasil tes belajar.

Metode pengumpulan data dalam penelitian ini adalah dengan teknik angket untuk mengetahui kelayakan media dari ahli materi dan ahli media serta respon maha- siswa dan dosen, teknik observasi untuk mengetahui keterlaksanaan tahapan pro- blem based learning dipadu pendekatan BLESS dan teknik tes koginitif untuk penilaian prestasi belajar ditinjau dari ketuntasan secara klasikal.

Prosedur penelitian meliputi 9 tahapan antara lain: tahap pendahuluan, dengan studi pustaka untuk mempelajari teori dan konsep serta penelitian sebelumnya yang berkaitan dengan media yang akan dikembangkan serta melakukan studi lapangan dengan observasi dan wawancara di kampus. Tahapan pengembangan meliputi pembuatan desain media berbasis aplikasi pada handphone, untuk kemudian dikonsultasi- kan dengan dosen pembimbing selaku konsultan ahli. Langkah berikutnya adalah validasi media berbasis aplikasi pada handphone oleh ahli materi/ desain pembe- lajaran dan ahli media untuk selanjutnya direvisi sesuai saran dan dilakukan uji coba awal. Hasil saran akan direvisi untuk kemudian diujicobakan pada tahap uji coba utama. Hasil saran akan direvisi untuk kemudian diujicobakan pada uji coba operasional. Pada uji coba ini dilakukan pada kelas kontrol dan eksperimen untuk mengetahui keefektifan media berbasis aplikasi pada handphone yang dikembangkan. Hasil saran pada uji coba operasional, yang dilakukan pada 2 kelas kemudian revisi untuk menjadi produk akhir.

Data validasi oleh ahli materi dan media dinalisis dengan menggunakan formula Gregory (Gregory, 2007). Nilai Content
Validity $(\mathrm{CV})>0,7$ maka media yang dikembangkan dikatakan layak sehing- ga dapat dilanjutkan ke tahap uji coba. Teknik analisa data survei di lapangan terhadap dosen dan mahasiswa menggu- nakan skala Gutman dengan jawaban ya dan tidak, selanjutnya dianalisis dengan perhi- tungan persentase menurut Arikunto (2006). Hasil presentase tersebut dikelompokkan menurut kriteria kelayakan media menurut Riduwan (2008).

\section{Hasil Penelitian dan Pembahasan}

Berdasarkan hasil analisis data, dapat disimpulkan: 1) hasil tiap tahap penelitian dan pengembangan pada: tahap studi pendahuluan disimpulkan bahwa dibutuhkan media berupa aplikasi pada handphone untuk mendukung pembelajaran mata kuliah media reagen dengan model PBL dipadu pendekatan BLESS (Blended Learning Systems Structure). Tahap pengembangan produk awal dihasilkan draft yang berupa aplikasi pada handphone yaitu LEMMPER (Learning Media Mobile Program Enriched \& Refined); tahap uji coba awal dengan total responden adalah 2 dosen dan 6 mahasiswa reguler 2A. Saran dari dosen dan mahasiswa yang diperoleh kemudian dilakukan per- baikan sehingga dihasilkan revisi 1 seperti yang disajikan pada Tabel 2 .

\begin{tabular}{|c|c|c|}
\hline No & Saran & Perbaikan \\
\hline 1 & $\begin{array}{l}\text { Tampilan aplikasi tidak } \\
\text { jelas, jika diinstal pada } \\
\text { tablet. }\end{array}$ & $\begin{array}{l}\text { Resolusi aplikasi diting- } \\
\text { katkan untuk instalasi } \\
\text { pada tablet. }\end{array}$ \\
\hline 2 & $\begin{array}{l}\text { Tombol navigasi susah } \\
\text { dijalankan untuk hand- } \\
\text { phone touchscreen, ha- } \\
\text { nya bisa digunakan un- } \\
\text { tuk handphone dengan } \\
\text { tombol keypad. }\end{array}$ & $\begin{array}{l}\text { Penambahan fitur tom- } \\
\text { bol navigasi virtual } \\
\text { yang dapat dijalankan } \\
\text { untuk layar handphone } \\
\text { touchscreen. }\end{array}$ \\
\hline 3 & $\begin{array}{l}\text { Terdapat beberapa pe- } \\
\text { ngetikan suku kata yang } \\
\text { salah. }\end{array}$ & $\begin{array}{l}\text { Memperbaiki pengetikan } \\
\text { suku kata yang salah } \\
\text { seperti : } \mathrm{HCl} \text { pkat men- } \\
\text { jadi } \mathrm{HCl} \text { pekat }\end{array}$ \\
\hline 4 & $\begin{array}{l}\text { Video yang ditampilkan } \\
\text { kurang menarik. }\end{array}$ & $\begin{array}{l}\text { Mengganti video yang } \\
\text { semula hasil pengun- } \\
\text { duhan di youtube dengan } \\
\text { video hasil buatan maha- } \\
\text { siswa sendiri. }\end{array}$ \\
\hline 5 & $\begin{array}{l}\text { Visual dan audio pada } \\
\text { video kurang jelas. }\end{array}$ & $\begin{array}{l}\text { Memberikan alamat web } \\
\text { site untuk mengunduh } \\
\text { video dengan kualitas } \\
\text { lebih bagus. }\end{array}$ \\
\hline 6 & $\begin{array}{l}\text { Background media ku- } \\
\text { rang menarik }\end{array}$ & $\begin{array}{l}\text { Mengganti background } \\
\text { media menjadi lebih } \\
\text { menarik }\end{array}$ \\
\hline
\end{tabular}


Tahap uji berikutnya dilakukan uji coba utama dengan jumlah total responden adalah 2 dosen dan 30 mahasiswa yang terdiri dari 15 mahasiswa reguler $2 \mathrm{~B} 1$ dan 15 mahasiswa reguler 2B2. Saran dari dosen dan mahasiswa yang diperoleh kemudian dilakukan perbaikan sehingga dihasilkan revisi 2 seperti tersaji pada Tabel 3 .

Tabel 3. Revisi 2

\begin{tabular}{|c|c|c|}
\hline No & Saran & Perbaikan \\
\hline 1 & $\begin{array}{l}\text { Terlalu banyak gambar } \\
\text { sehingga terkesan ramai. }\end{array}$ & $\begin{array}{l}\text { Mengurangi gambar yang } \\
\text { tidak berhubungan de- } \\
\text { ngan materi. }\end{array}$ \\
\hline 2 & $\begin{array}{l}\text { Penomoran soal evaluasi } \\
\text { tidak urut. }\end{array}$ & $\begin{array}{l}\text { Penomoran soal evaluasi } \\
\text { diurutkan. }\end{array}$ \\
\hline 3 & Video susah diunduh. & $\begin{array}{l}\text { Merubah direktori un- } \\
\text { duhan video yang semua } \\
\text { di youtube menjadi di } \\
\text { server AAK Nasional } \\
\text { Surakarta. }\end{array}$ \\
\hline 4 & Video tidak bersuara. & $\begin{array}{l}\text { Mengunggah ulang video } \\
\text { yang telah dicek kualitas } \\
\text { audio. }\end{array}$ \\
\hline 5 & $\begin{array}{l}\text { Terdapat pengetikan su- } \\
\text { ku kata yang salah se- } \\
\text { perti tmbangan dan } \\
\text { corng }\end{array}$ & $\begin{array}{l}\text { Memperbaiki pengetikan } \\
\text { suku kata yang salah } \\
\text { seperti tmbangan menjadi } \\
\text { timbangan dan corng } \\
\text { menjadi corong. }\end{array}$ \\
\hline 6 & $\begin{array}{l}\text { Ukuran huruf pada soal } \\
\text { evaluasi terlalu kecil } \\
\text { sehingga tidak terbaca } \\
\text { dengan jelas. }\end{array}$ & $\begin{array}{l}\text { Mengganti huruf pada } \\
\text { soal evaluasi menjadi } \\
\text { lebih besar sehingga } \\
\text { terbaca dengan jelas. }\end{array}$ \\
\hline 7 & $\begin{array}{l}\text { Soal evaluasi terlalu } \\
\text { sedikit. }\end{array}$ & Menambah soal evaluasi. \\
\hline
\end{tabular}

Tahap uji berikutnya dilakukan uji coba operasional dengan jumlah total responden adalah 2 dosen dan 81 mahasiswa yang terdiri dari 41 mahasiswa reguler $2 \mathrm{~A}$ dan 40 mahasiswa reguler 2 C. Saran dari dosen dan mahasiswa yang diperoleh kemu- dian dilakukan perbaikan sehingga diha- silkan revisi 2 seperti tersaji pada Tabel 4 .

Tabel 4. Saran Dosendan Mahasiswa dan Perbaikan pada

\begin{tabular}{|c|c|c|}
\hline No & Saran & Perbaikan \\
\hline 1 & $\begin{array}{l}\text { Instruksi tentang cara } \\
\text { penggunaan aplikasi ku- } \\
\text { rang jelas. }\end{array}$ & $\begin{array}{l}\text { Memperjelas instruksi } \\
\text { dengan menambahkan } \\
\text { informasi tentang cara } \\
\text { penggunaan aplikasi. }\end{array}$ \\
\hline 2 & $\begin{array}{l}\text { Di beberapa background } \\
\text { halaman, tulisan tidak } \\
\text { terlihat jelas }\end{array}$ & $\begin{array}{l}\text { Mengganti warna } \\
\text { background yang kon- } \\
\text { tras dengan warna } \\
\text { tulisan, sehingga tu- } \\
\text { lisan terlihat jelas. }\end{array}$ \\
\hline 3 & $\begin{array}{l}\text { Prosedur pembuatan } \\
\text { reagen kuantitatif ada } \\
\text { yang kurang. }\end{array}$ & $\begin{array}{lr}\text { Melengkapi } & \text { prosedur } \\
\text { pembuatan } & \text { reagen } \\
\text { kuantitatif. } & \end{array}$ \\
\hline 4 & $\begin{array}{l}\text { Tata penulisan daftar } \\
\text { pustaka ada yang salah. }\end{array}$ & $\begin{array}{l}\text { Memperbaiki tata pe- } \\
\text { nulisan daftar pustaka. }\end{array}$ \\
\hline
\end{tabular}

Hasil penilaian kelayakan media ditinjau dari aspek materi/ desain pembelajaran oleh dosen saat uji coba dilakukan dengan mengisi angket penilaian yang diberikan, Hasil penilaian kelayakan media dapat dilihat pada Tabel 5 .

Tabel 5. Rerata Skor Penilaian Kelayakan Media Aspek Materi oleh Dosen pada Uji Coba Awal, Utama dan Operasional

\begin{tabular}{ccccc}
\hline No & Uji lapangan & $\begin{array}{c}\sum \\
\text { respon } \\
\text { den }\end{array}$ & $\begin{array}{c}\text { Rerata } \\
\text { skor }\end{array}$ & Kategori \\
\hline 1 & Awal & 2 & 95,83 & sangat layak \\
2 & Utama & 2 & 87,50 & sangat layak \\
3 & Operasional & 2 & 87,50 & sangat layak \\
\hline
\end{tabular}

Keterangan : rentang skor adalah 1-100

Hasil penilaian kelayakan media ditinjau dari aspek media oleh dosen saat uji coba, dapat dilihat pada Tabel 6 .

Tabel 6. Rerata Skor Penilaian Kelayakan Media Aspek Media oleh Dosen pada Uji Coba Awal, Utama dan Operasional

\begin{tabular}{ccccc}
\hline No & Uji lapangan & $\begin{array}{c}\sum \\
\text { respon } \\
\text { den }\end{array}$ & $\begin{array}{c}\text { Rerata } \\
\text { skor }\end{array}$ & Kategori \\
\hline 1 & Awal & 2 & 87,50 & sangat layak \\
2 & Utama & 2 & 87,50 & sangat layak \\
3 & Operasional & 2 & 87,50 & sangat layak \\
\hline Keterangan $:$ rentang skor adalah $1-100$ &
\end{tabular}

Keterangan : rentang skor adalah 1-100

Berdasarkan hasil pada Tabel 5 dan Tabel 6, kriteria kelayakan media ditinjau dari aspek materi skor penilaian mengalami penurunan, tetapi masih dalam kategori "sangat layak", hal ini disebabkan pada tahap uji berikutnya, berbagai perbaikan terhadap media yang dilakukan peneliti kurang terintegrasi, sehingga media menjadi kurang optimal untuk difungsikan sebagai media pendukung pembelajaran mata kuliah media reagen dengan model PBL dengan pendekatan BLESS. Kriteria kelayakan media ditinjau dari aspek media skor penilaian tidak mengalami perubahan karena per- baikan dari media dari aspek materi tidak banyak. Hasil penilaian kelayakan media ditinjau dari aspek materi oleh mahasiswa saat uji coba disajikan pada Tabel 7. 
Tabel 7. Rerata Skor Penilaian Kelayakan Media Aspek Materi oleh Mahasiswa pada Uji Coba Awal, Utama dan Operasional

\begin{tabular}{ccccc}
\hline No & Uji lapangan & $\begin{array}{c}\sum \\
\text { respon } \\
\text { den }\end{array}$ & $\begin{array}{c}\text { Rerata } \\
\text { skor }\end{array}$ & Kategori \\
\hline 1 & Awal & 6 & 93,06 & sangat layak \\
2 & Utama & 30 & 92,23 & sangat layak \\
3 & Operasional & 81 & 93,19 & sangat layak \\
\hline \multicolumn{4}{l}{ Keterangan : rentang skor adalah 1-100 }
\end{tabular}

Hasil penilaian kelayakan media ditinjau dari aspek media oleh mahasiswa saat uji coba, dapat dilihat pada Tabel 8 .

\begin{tabular}{ccccc} 
Tabel 8. Rerata & $\begin{array}{c}\text { Skor Penilaian } \\
\text { Media oleh Mahasiswa } \\
\text { dan Operasional }\end{array}$ & $\begin{array}{c}\text { Kelayakan Mji Coba Awal, Utama } \\
\text { pada Aspek }\end{array}$ \\
\hline No & Uji lapangan & $\begin{array}{c}\sum \\
\text { respon } \\
\text { den }\end{array}$ & $\begin{array}{c}\text { Rerata } \\
\text { skor }\end{array}$ & Kategori \\
\hline 1 & Awal & 6 & 91,67 & sangat layak \\
2 & Utama & 30 & 89,15 & sangat layak \\
3 & Operasional & 2 & 88,0 & sangat layak \\
\hline Keterangan : rentang skor adalah 1-100
\end{tabular}

Berdasarkan hasil pada Tabel 7 dan Tabel 8, kriteria kelayakan media ditinjau dari aspek materi pada uji coba utama skor penilaian mengalami penurunan dibandingkan denga uji coba awal, tetapi masih dalam kategori "sangat layak", hal ini disebabkan pada tahap uji coba utama banyak mahasiswa yang tidak dapat meng- gunakan media LEMMPER di handphone mereka karena proses intalasi media pada saat proses pembelajaran yang terlalu lama, sehingga tidak semua mahasiswa dapat menggunakan media tersebut. Skor penilaian pada uji coba operasional mengalami peningkatan karena semua mahasiswa sudah dapat memanfaatkan media secara optimal untuk mendukung pembelajaran mata kuliah media reagen dengan model PBL dipadu pendekatan BLESS. Kriteria kelayakan media ditinjau dari aspek media, skor penilaian mengalami penurunan karena perbaikan dari media oleh peneliti dari aspek media kurang terintegrasi, seperti perbaikan video pembelajaran dengan kualitas video lebih bagus menyebabkan ukuran aplikasi menjadi lebih besar, hal ini menyebabkan handphone menjadi error.

Aplikasi LEMMPER yang semula hanya dijalankan dengan bahasa program java harus mengalami beberapa perubahan bahasa program seperti APK (Android Package) untuk handphone dengan sistem operasi android. Allen \& Meyer (1997) mengaitkan antara jenis media pembelajaran dan tujuan pembelajaran yang akan dicapai. Allen melihat bahwa, media tertentu memiliki kelebihan untuk tujuan belajar tertentu tetapi lemah untuk tujuan belajar yang lain. LEMMPER mempunyai kele- bihan terkait sebagai media pendukung mata kuliah media reagen dengan model PBL dipadu pendekatan BLESS, yaitu media ini mempunyai kelebihan didalam memberikan informasi dengan pengenalan secara visual melalui video streaming pembuatan reagen, dan penggambaran prosedur pembuatan reagen yang sesuai dengan standar kom- petensi yang ingin dicapai. Selain itu terdapat beberapa perbedaan antara media pembelajaran yang saat ini digunakan yaitu Microsoft Office PowerPoint dengan media LEMMPER yang dikembangkan peneliti seperti yang tersaji dalam tabel 9 .

Tabel 9.Perbedaan LEMMPER dengan Microsoft Office PowerPoint

\begin{tabular}{|c|c|c|c|}
\hline No & Aspek & LEMMPER & $\begin{array}{c}\text { Microsoft } \\
\text { Office } \\
\text { PowerPoint }\end{array}$ \\
\hline 1 & $\begin{array}{l}\text { Penyajian } \\
\text { materi }\end{array}$ & $\begin{array}{l}\text { Media } \\
\text { dilengkapi } \\
\text { dengan } \\
\text { soal - soal } \\
\text { evaluasi yang } \\
\text { interaktif. }\end{array}$ & $\begin{array}{l}\text { Media tidak } \\
\text { dilengkapi soal } \\
\text { - soal evaluasi } \\
\text { yang interkatif. }\end{array}$ \\
\hline 2 & Portabilitas & $\begin{array}{l}\text { Media dapat } \\
\text { di instal di } \\
\text { semua jenis } \\
\text { handphone } \\
\text { berwarna. }\end{array}$ & $\begin{array}{l}\text { Media tidak } \\
\text { dapat di instal } \\
\text { di semua jenis } \\
\text { handphone } \\
\text { berwarna. }\end{array}$ \\
\hline 3 & Ukuran file & $\begin{array}{l}\text { Ukuran file } \\
\text { lebih kecil } \\
\text { dengan } \\
\text { tampilan slide } \\
\text { yang sama. }\end{array}$ & $\begin{array}{l}\text { Ukuran file } \\
\text { lebih besar } \\
\text { dengan } \\
\text { tampilan slide } \\
\text { yang sama. }\end{array}$ \\
\hline
\end{tabular}

Keterlaksanaan tahapan Problem Based Learning diperoleh rata-rata penilaian dengan kategori "sangat layak", rata-rata angket respon mahasiswa dan dosen pada semua uji diperoleh penilaian dengan kategori "sangat layak", dan keefektifan penggunaan media dilihat dari persentase ketuntasan hasil belajar mahasiswa pada pembelajaran mata 
kuliah media reagen dengan model PBL dipadu Pendekatan BLESS (Blended Learning Systems Structure) di kelas reguler 2C AAK Nasional Surakarta sebesar $100 \%$ sehingga dinyatakan tuntas secara klasikal.

\section{Kesimpulan dan Rekomendasi}

\section{Kesimpulan}

Berdasarkan analisis data dan pembahasan didapatkan beberapa kesim- pulan sebagai berikut:

1. Hasil tiap tahapan pengembangan media untuk mendukung pembelajaran mata kuliah media reagen dengan model PBL dipadu pendekatan BLESS yang me- ngacu siklus R\&D Borg and Gall, pada:

a. Tahap studi pendahuluan disimpulkan bahwa dibutuhkan media berupa aplikasi pada handphone untuk mendukung pembelajaran mata kuliah media reagen dengan model PBL dipadu Pendekatan BLESS.

b. Tahap pengembangan produk awal dihasilkan draft yang berupa aplikasi pada handphone yaitu LEMMPER (Learning Media Mobile Program Enriched \& Refined).

c. Tahap uji coba awal dihasilkan revisi 1 .

d. Tahap uji coba lapangan dihasilkan revisi 2, data keterlaksanaan tahapan Problem Based Learning, dan hasil belajar mahasiswa.

e. Tahap uji coba operasional dihasilkan produk akhir.

2. Kualitas produk pengembangan yang berupa media yaitu aplikasi pada handphone untuk mendukung pembelajaran mata kuliah media reagen dengan model PBL dipadu pendekatan BLESS berdasarkan:

a. Hasil penilaian ahli materi dan ahli media diperoleh $\mathrm{CV}>0,7$ yang menunjukkan bahwa media dapat digunakan ke tahap uji coba.

b. Angket respon mahasiswa dan dosen pada uji coba awal diperoleh penilaian dengan kategori " sangat layak". Angket respon mahasiswa dan dosen pada uji coba lapangan diper- oleh penilaian dengan kategori "sangat layak". Angket respon maha- siswa dan dosen pada uji coba operasional diperoleh penilaian dengan kategori “ sangat layak".

3. Media yang dikembangkan untuk mendukung pembelajaran mata kuliah media reagen dengan model PBL dipadu pendekatan BLESS telah digunakan dalam pembelajaran dengan hasil perolehan persentase sebesar $100 \%$ untuk ketuntasan klasikal ketika diujicobakan di kelas reguler 2C Akademi Analis Kesehatan Nasional Surakarta.

\section{Rekomendasi}

Berdasarkan kesimpulan dan implikasi dalam penelitian ini, maka peneliti mengajukan rekomendasi sebagai berikut:

1. Rekomendasi untuk dosen

Sebelum dosen menggunakan media LEMMPER pada mata kuliah media reagen dengan model PBL dipadu pendekatan BLESS, hendaknya dosen memahami terlebih model pembelajaran PBL yang dipadu dengan pendekatan BLESS, selain itu dosen harus memas- tikan jenis handphone yang digunakan oleh mahasiswa, karena format file untuk aplikasi handphone harus sesuai dengan sistem operasi yang digunakan.

2. Rekomendasi untuk peneliti lain

a. Hasil penelitian ini dapat digunakan sebagai acuan untuk penelitian berikutnya yang sejenis dengan materi yang berbeda.

b. Hendaknya sebelum penelitian, mahasiswa yang dijadikan sampel sudah pernah menggunakan model pembelajaran PBL yang dipadu dengan pendekatan BLESS, agar pada saat penelitian berlangsung tidak terda- pat masalah yang berhubungan de- ngan model pembelajaran.

c. Dalam memilih validator untuk penelitian dan pengembangan media hendaknya disesuaikan dengan karakteristik media yang dikembangkan. 
3. Rekomendasi bagi Pengelola Pendidikan Media LEMMPER adalah media yang efektif digunakan untuk pembelajaran media reagen, oleh sebab itu hendaknya pengelola pendidikan mendukung dosen dosen kimia untuk menyusun media LEMMPER dengan diadakan workshop pembuatan media LEMMPER.

4. Rekomendasi untuk Mahasiswa

a. Mahasiswa dalam menggunakan me- dia LEMMPER untuk mendukung pembelajaran mata kuliah media reagen dengan model PBL dipadu pendekatan BLESS hendaknya me-ngikuti proses belajar mengajar de- ngan aktif, antusias sehingga dapat mendalami materi yang diajarkan dengan baik.

b. Pembelajaran menggunakan media LEMMPER untuk mendukung pembelajaran mata kuliah media reagen dengan model PBL dipadu pen- dekatan BLESS memerlukan kerja sama antar mahasiswa, sehingga semua mahasiswa dapat memahami materi dengan baik.

\section{Daftar Pustaka}

Akinoglu, O. \& Tandogan, R. O. (2007). The Effect of Problem Based Active Learning in Science Education on Student's Academic Achievement, Attitude and Concept Learning. Eurasia Journal of Mathematics, Science and Technology Education, 3(1), $71-81$.

Allen, M .J. dan Meyer, J. P. (1997). Commit ment in the Workplace Theory Research\& Application. California: Sage Publication.

Arikunto, S. (2006). Dasar-Dasar Evaluasi Pendidikan. Jakarta: Bumi Aksara.

BAAK Akademi Analis Kesehatan Nasional Surakarta.

Borg, W. R. \& Gall, M. D. (1983). Educational Research an Introduction. New Yorkand London: Longman Inc.

Dahar, R. W. (2006). Teori-Teori Belajar. Jakarta: Erlangga.

Delialioglu, O. (2012). Student Engagement in Blended Learning Enviroments with Lecture - Based and Problem - Based
Instruc- tional Approach. Educational Technology \& Society, 15(3), 310-322.

Gregory, R. J. (2007). Psychological Testing History, Principles, and Applications,5th Edition. Boston: Pearson Education, Inc.

Gustavo, Z. \& Nussbaum, M. (2004). A Constructivist Mobile Learning Environment Supported by A Wireless Handheld Network. Journal of Computer Assisted Learning, 20(4), 235-243.

Staker, H., Horn, M. B., Christensen C. M. (2012). Blended: Using Disrup tive Innovationto Improve Schools. Jossey Bass. A Wiley Brand: San Fransisco.

Izzaty, R. E. (2006). Problem Based Learning dan Pembelajaran di Perguruan Tinggi. Jurnal Paradigma Universitas Negri Yogyakarta, 1(1), 77-83.

Peraturan Pemerintah pasal 2 tahun 1999 tentang Tujuan Pendidikan Tinggi.

Poon, J. (2013). Blended Learning: An Institutional Approach for Enhancing Students' Learning Experiences. Journal of online learning andteachingi, 9(2), 271-288.

Riduwan. (2008). Skala Pengukuran Variabel Variabel Penelitian. Bandung: Alfabe- ta.

Undang - Undang Republik Indonesia No 20 pasal 19 Tahun 2003 tentang Sistem Pendidikan Nasional. 